東北地方の外国人住民を対象とした方言理解支援ツールにお ける翻訳上の問題点

一東北諸方言とポルトガル語の対照研究—

\title{
TRANSLATION ISSUES IN THE DIALECT \\ COMPREHENSION SUPPORT TOOL FOR \\ FOREIGN RESIDENTS IN THE TOHOKU REGION: \\ CONTRASTIVE RESEARCH OF TOHOKU DIALECT \\ AND PORTUGUESE LANGUAGE ${ }^{1}$
}

斎藤 敬太 ${ }^{2}$

要旨：東北地方の外国人住民の方言理解支援ツールとして作成した『東北地方の 外国人住民のための「くらしの方言集」』(“Coleção de Dialetos da Vida Diária” para estrangeiros residentes da região de Tohoku no Japão）において採用したポルトガル語翻訳 について、東北方言からの翻訳上の問題点を考察するために、翻訳した各単語につい てポルトガル語翻訳者への聞き取り調査を実施した。その結果、東北方言からポルト ガル語へ翻訳する際の言語学的な問題点には、「I 意味論的問題」として「I-a. 方言のほうがポルトガル語より意味範疇が広い」「I-b。方言のほうがポルト ガル語より意味範疇が狭い」「I-c． ポルトガル語に適切な語がなく説明的 になる」の3つの場合が存在し、「II 意味論以外の問題」として「II-a． 発音規 則」「II-b. 語順」「II-c. テンス・アスペクト」「II-d. 人称」「II-e. 対象」「II-f。言い回し」の6つがあることが明らかになった。 キーワード : 東北方言、外国人住民、ポルトガル語、意味範疇のずれ、対照研究

Resumo: Para observar os problemas de tradução do dialeto de Tohoku para o português da "Coleção de Dialetos da Vida Diária", produzida como ferramenta de auxílio à compreensão de dialetos para estrangeiros residentes na região de Tohoku, fizemos uma entrevista sobre cada palavra traduzida com o tradutor de português. O resultado mostrou problemas linguísticos no ato de tradução. Destes, como "I. Problemas semânticos", tivemos 3: I-a. Categorias de significados

1 Article received 30 December 2017 and accepted 6 May 2018

2 Doutor pela Tokyo Metropolitan University, Professor colaborador da Tsuda University, Tóquio, Japão; saito.keita.socioling@gmail.com (ORCID iD https://orcid.org/0000-0002-3878-1020). 
dos dialetos mais amplas que no português; I-b. Categorias de significados do português mais amplas que nos dialetos; I-c. Explicação por não existir uma palavra correspondente no português. Como "II. Outros problemas além dos semânticos", tivemos 6: II-a. Regras de pronúncia; II-b. Ordem das palavras; II-c. Tempo e aspecto; II-d. Pessoa; II-e. Objeto; II-f. Expessão.

Palavras-chave: Dialeto de Tohoku, estrangeiros residentes, português, diferenças nas categorias de significados, pesquisa comparativa

\section{1. はじめに}

2011年の東日本大震災により、一時約 6,000人の外国人住民が去った東 北地方であるが、2013年以降は再び増加に転じ、2016年12月現在では52, 298 人 3 となり、震災前である 2010 年の 48,732 人を上回った（図1）。

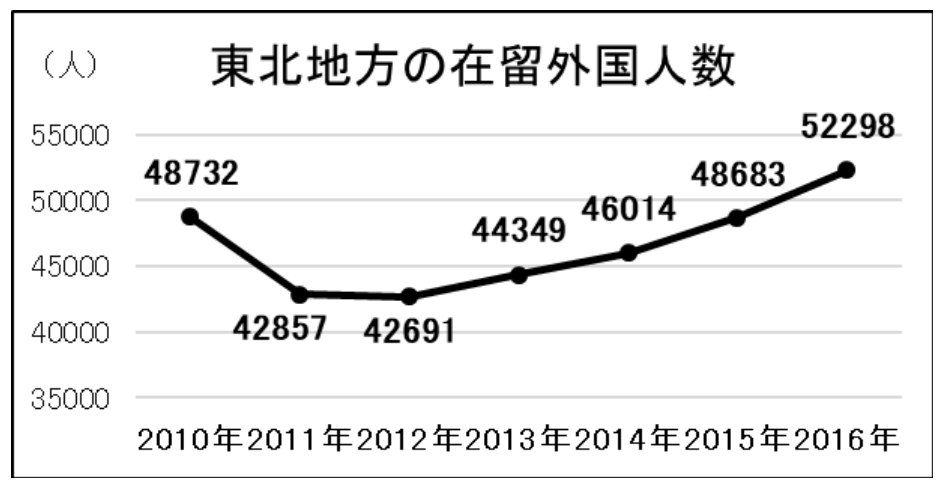

図1. 東北地方の在留外国人数

この東北地方では、標準語とは異なる特徵を多く持つ方言が話されてお り、比較的多くの人々が老若男女問わず方言を話している。そこで筆者は、 東北地方の外国人住民の必要最低限の方言理解への支援を目的として、主に 東北地方の日本人を対象として実施した「方言使用調査」（斎藤2018b）、「 方言使用調査」の結果をもとに東北地方の外国人住民に対して実施した「方 言理解調査」、この $2 つ の$ 調査から図2のようなCD付き小冊子『東北地方の外 国人住民のための「くらしの方言集」』(“Coleção de Dialetos da Vida Diária” para estrangeiros residentes da região de Tohoku no Japão）（斎藤2017、以下「方言 集」）を作成し、東北各県・各市町村の国際交流協会に設置していただき、 外国人住民や地域日本語ボランティア教師を主な対象として配布していただ いている。また、ウェブサイト（http://saitokeita.web.fc2.com/hougenshu）では 方言集のPDF版及び方言集に収録できなかった「例文の翻訳」を公開してい

3 総務省 (2017) の「16-12-04 都道府県別 国籍・地域別 在留外国人」より 
る。この方言集は、標準語による解説のみならず、英語・中国語・韓国語・ ポルトガル語・インドネシア語の翻訳も記載した。東北地方には現在そ こまで多くのポルトガル語母語話者がいるわけではないが、日本国内には 2016年 12 月現在で 180,923 人のブラジル人が居住している。これは日本国内 の外国人では5番目に多い数である。在日ブラジル人の多くは日系人として 定住・永住している者が多く、近年では全国的に人手不足と言われる介護 福祉士等の介護分野を目指すケースもあるため（堀2009）、在日ブラジル 人の他地域からの移動の可能性等も考慮してポルトガル語による翻訳も記 載することにした。

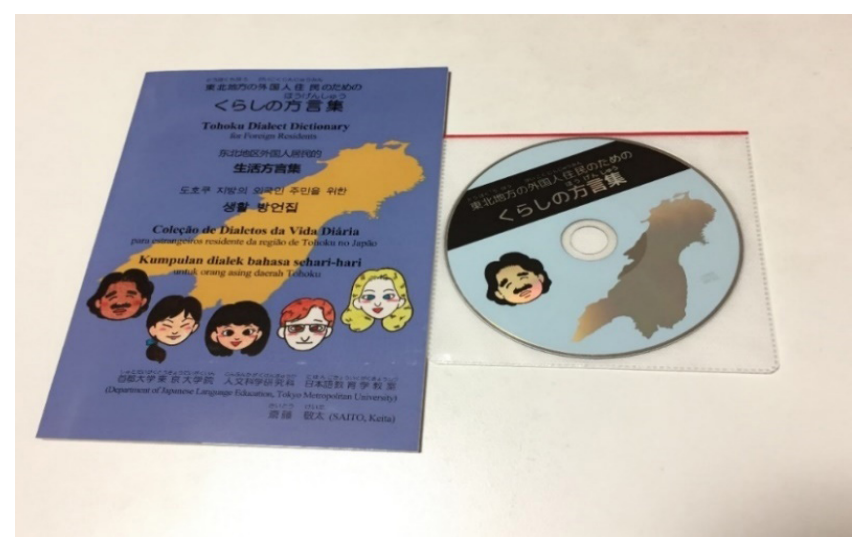

図2.『東北地方の外国人住民のための「くらしの方言集」』

これまでの東北方言と非地元出身者に関する研究としては、竹田 (2012) のような他地方出身の日本語母語話者を対象としたもの、後藤 (2015)のよう な外国人留学生を対象としたもの、山下 (2014)のような外国人住民を対象と したものに分けられるが、いずれもポルトガル語母語話者を対象としたもの については管見の限り見られず、また、東北方言と外国人の母語という観点 からの対照研究についても見当たらない。

また、ある語から別の言語へ翻訳される際、類似の意味を持つ語同士 でもその意味範疇にずれが生じることが少なくない。斎藤・志喜屋 (2015) で は、日本国内に見られる日本語とポルトガル語・スペイン語が併記された多 言語表示の意味範疇のずれについて取り上げられている4。方言集の翻訳を作 成する際も、このような意味範疇のずれについて考える必要がある。

これまで外国語との対照研究は標準語を用いたものが一般的である（太 田2000、儀保 2014など）が、東北方言を考える際に、果たして標準語との対 照をそのまま適用できるのだろうか。具体例を見て考える。なお、以降方言

4 斎藤・志喜屋 $(2015)$ pp. 116-119 
形式は【】、それに相当する標準語は《》、具体的な意味は〔〕で括 ることにする。また、方言形式によってはいくつかのバリエーションが存在 することがあるが、その場合は【めごい（めんこい、めんけ、めげー）】 標準語《かわいい》に当たる東北方言）のように複数の形式を記す。

例えば、東北地方全域で用いられる【なげる】は、標準語《なげる》と 同語形であるが、その意味は〔投げる〕以外にも〔捨てる〕という意味も持 ち合わせている。標準語においては《なげる》と《すてる》という別語形で 示すことになる。これについてポルトガル語を考えると、〔投げる〕意味を 持つ語としてはjogarやbotarが該当する。そしてこれらの語は（副詞foraを付属 する必要があるものの）〔捨てる〕意味も持ち合わせる。その点において、 標準語《なげる》や《すてる》よりも東北方言【なげる】のほうがポルトガ ル語に近いと考えることができる5。これを表に示すと表1のようになる。

表1．標準語よりも東北方言のほうがポルトガル語と語の意味が近い場合

\begin{tabular}{|c|c|c|}
\hline 標準語 & 《なげる》 & 《すてる》 \\
\hline 東北方言 & \multicolumn{2}{|c|}{ 【なげる】 } \\
\hline ポルトガル語 & \multicolumn{2}{|c|}{ jogar, botar } \\
\hline
\end{tabular}

このことから、標準語を介した対照では東北方言においては必ずしもそ のまま適用できないことが言える。筆者の作成した方言集は前述の通り東北 地方の外国人住民が使用するものであるが、あえて東北方言と意味がずれた 標準語を介さずに彼らの母語から直接東北方言を考えたほうが効率的な場合 があるのだ。

また、日本において外国語訳を付す場合に英語が最もよく用いられている が、外国語との対照について、英語について考えればそれでよいのだろうか。

例えば、主に宮城県や岩手県などで用いられている【すける】は〔手伝 う〕意味である。これに該当する英語はhelpであるが、この場合〔手伝う〕以 外にも〔救助する〕意味も含まれる。一方、ポルトガル語を考えると、【す ける】に該当する語はajudarであり、こちらは〔手伝う〕のみを指し、〔救助 する】はsocorrerと別語で表現するため、むしろポルトガル語のほうが東北方 言に近い。これを表に示すと表2のようになる。

5 Jogarやbotarはそれぞれ〔投げる〕や〔捨てる〕以外の意味も持っており、厳密には東北方 言【なげる】とは全く同じというわけではない。しかし、同じではない部分においては標 準語《なげる》や《すてる》でも東北方言同様ポルトガル語とは一致しないので、ここで はその部分については特に触れない。 
表2. 英語よりもポルトガル語のほうが語の東北方言の語と意味が近い場合

\begin{tabular}{|c|c|c|}
\hline 英語 & \multicolumn{2}{|c|}{ help } \\
\hline 東北方言 & 【すける】 & 【たすける】 \\
\hline ポルトガル語 & ajudar & socorrer \\
\hline 意味 & 〔手伝う〕 & 〔救助する〕 \\
\hline
\end{tabular}

このように、標準語同様、英語との対照についても、そのまま外国人住 民の母語（本稿ではポルトガル語）には当てはまらず、むしろ彼らの母語で 考えたほうが良い場合が見られる。

本稿では、東北方言とポルトガル語において直接的な対照研究を行うこ とで、東北地方のポルトガル語母語話者に関連し得る翻訳上の問題点につい て考察していく。

\section{2. 本稿における東北方言}

東北地方の方言は新潟県北部や関東地方北部と連続体をなしているた め、どこまでを東北方言とするかについてこれまでいくつかの区分がなさ れてきた（日本方言研究会編1964、本堂1967、飯豊・日野編1982など）。 方言集ではあくまでも東北6県を対象としており、また、方言区分はおおよ その方言分布を示すことを目的とした。したがって、これまでの研究を参 考にしつつ、各地域の様々な要因を勘案し、かつ方言集の主な利用者とし て想定した外国人住民や地域日本語ボランティア教師といった方言学の非 専門家にもわかりやすいように以下の14区分を決定した（図3）。各県別に 見ると以下の通り。

青森県…津軽方言（青森県西部）、南部方言（青森県東部）

岩手県…南部方言（岩手県中部〜北部、青森県の南部方言と同じ）、伊達方 言（岩手県南部）、気仙方言（岩手県南東部）

宮城県…仙台方言

秋田県…秋田方言、鹿角方言（秋田県北東部）

山形県…村山方言（山形県中部）、置賜方言（山形県南部）、最上方言（山 形県北部）、庄内方言（山形県西部）

福島県…会津方言（福島県西部）、中通り方言（福島県中部）、浜通り方言 （福島県東部） 


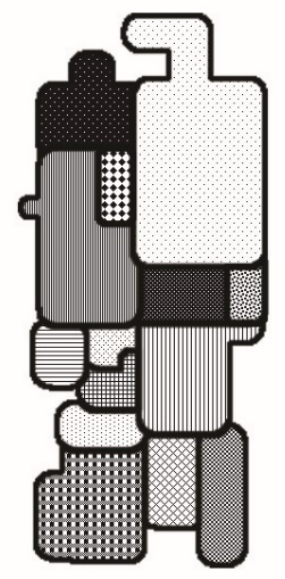

本稿においてもこの方言区分に準じ、また14区分の総称として「東北方 言」という語を用いる。なお、以下「東北方言」の表現として挙げる語は14 区分全てで用いられているものだけではなく、そのいずれかで用いられてい るものも含まれる。

\section{3. 問題の所在}

翻訳上の問題点を考える場合、先に述べたような意味範疇のずれによる 問題、すなわち意味論的問題を挙げることができる。そしてその中には、方 言のほうがポルトガル語より意味範疇が広い場合と、方言のほうがポルトガ ル語より意味範疇が狭い場合が考えられる。また、必ずしも対応する適切な 語がなく、説明的になってしまう場合もある。各問題点の詳細は後述してい くが、以上を表にすると表3のようになる。

表3．意味論的問題の種類

\begin{tabular}{|c|c|c|}
\hline \multicolumn{3}{|c|}{ I \begin{tabular}{c|} 
意味論的問題 \\
\hline I-a.
\end{tabular} I-b. } \\
方言のほうがポルトガル \\
$\begin{array}{c}\text { 語より意味範疇が広い } \\
\text { 方言のほがポルトガル } \\
\text { 語より意味範疇が狭い }\end{array}$ & $\begin{array}{c}\text { ポルトガル語に適切な語 } \\
\text { がなく説明的になる }\end{array}$ \\
\hline
\end{tabular}

では、意味範疇のずれが東北地方のポルトガル語を母語とする外国人 住民の言語生活において何を意味しているか、以下に具体的な例を挙げて 見てみる。 
例えば、東北地方全域で用いられる【あんべわり】は標準語でいう《 具合が悪い》に相当する語である。両方の表現にはa.〔体調が悪い〕とb. 都合が悪い]の二つの意味がある。すなわち【あんべわり】と《具合が悪 い》の意味範疇はほぼ同じと考えてよい。しかし、ポルトガル語の対応する 語で考えた場合、a.に該当するのはsentir-se malやestar doenteで、b.に該当す るのはnão ser convenienteとそれぞれ別の語で示すことになる（表4）。

表4.【あんべわり】の意味とポルトガル語の対応

\begin{tabular}{|c|c|}
\hline \multicolumn{2}{|c|}{ 東北方言【あんべわり】 } \\
\hline \multicolumn{2}{|c|}{ 標準語《具合が悪い》 } \\
\hline sentir-se mal, estar doente & não ser conveniente \\
\hline [体調が悪い] & [都合が悪い] \\
\hline
\end{tabular}

このように東北方言の表現がポルトガル語で二つの表現に相当する場 合、外国人住民（この例ではポルトガル語母語話者）にとってどのような 影響があるのだろうか。仮にポルトガル語母語話者の住民が長年東北に住 んでいて、自然習得によって方言を（ある程度）理解できるようになり、

【あんべわり】の意味を推測で理解しているつもりだとする。それを一義 的にsentir-se malの意味で理解しているとする。その場合、方言話者が部屋 に入ってきて「あんべわりなー。」（具合が悪いな。）と言ったら、「ど うしましたか? 大丈夫ですか?」とすぐに気遣うことができるだろう。し かし、方言話者にこれから出かけないかと誘った時に、「きょうは あん ベわりなー。」(今日は都合が悪いな。）と言われたら、（標準語の《具 合が悪い》もそうであるが）今日は体調が悪いというわけではなく、他の 予定があって出かけられないという意味である。この時に【あんべわり】 にnão ser convenienteの意味があることを知らないと、正しく理解できず、 病気で体調が良くないのか、といった不要な心配をすることになる（表5） 。この例は笑い話で斉むかもしれないが、全てにおいてそうとは限らず、 方言集では最低限の範囲内で過不足なくその意味を記述することが重要で あることを示している。 
表5.【あんべわり】の誤解

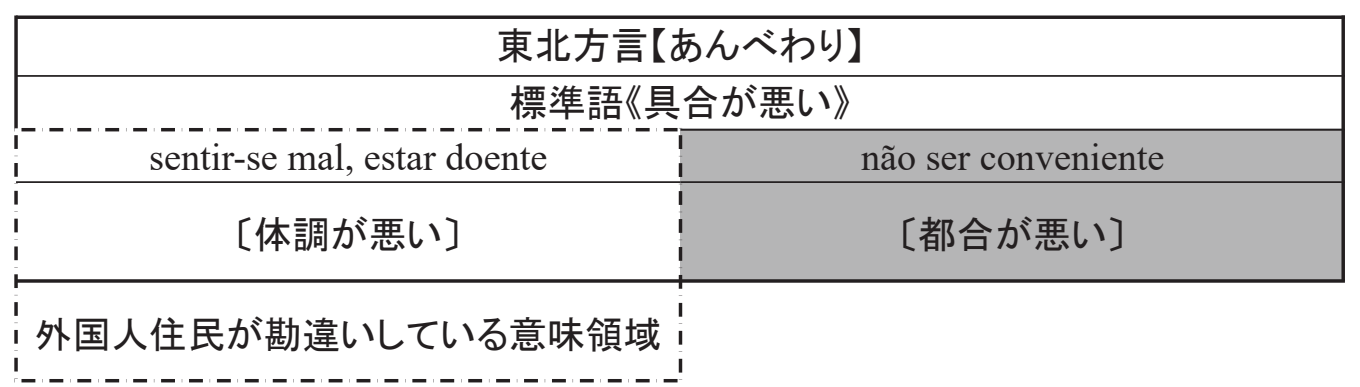

この意味だと誤解

実際はこの意味で使われた

\section{4. 方言集の概要}

本稿において研究対象となっている方言集について概説を加えておく。ま ず、日本人住民を主な対象とした「方言使用調査」で、予め用意した方言りス 卜を見てもらい、「使う」「聞く」ものについて尋亦た（斎藤2018b）。リス卜 に掲載した項目及び調查中に新たに得られた項目を合わせた計304項目から、調 查の結果多くの日本人住民が「使う」「聞く」としたものに項目を絞った。そ の後、絞った方言項目を含む会話を各地の方言話者に録音してもらい、東北地 方の外国人住民を対象に、録音を聞いてどの程度知っているかを問う「方言理 解調査」を実施した。外国人住民の理解度や方言項目の使用地域、急を要寸る 表現かなどを考慮し、また「方言理解調查」において外国人住民が知らなくて も文脈で推測できたものを除外するなどでさらに項目数を絞った結果、最終的 に118の方言項目を方言集に掲載することにした（斎藤2018a）。ポルトガル語 を始めとした多言語への翻訳依頼は最終的な項目数が決定する直前で行ってお り、実際に翻訳依頼した際は118項目より数項目多かった。なお、方言集に掲載 されていないものについても今後ウェブサイトで閲覧可能になる。また、方言 の翻訳に当たっては、まずは筆者が各方言項目及び各方言項目を用いた例文の 標準語訳を作成し、その標準語訳をポルトガル語等に翻訳してもらった。

\section{5. 調査方法}

本稿では、方言集用に翻訳を依頼した項目について、上述のような問題 点について考察していく。調查方法としては、ポルトガル語翻訳担当者に翻 訳依頼した際の翻訳リストを改めて見てもらいながら、インタビュー形式で 各項目の意味やその他ポルトガル語と東北方言との違いについて聞き取り調 査を実施した。

ポルトガル語翻訳担当者は、現在日本に居住するブラジル人男性であ る。彼は母国の大学において日本語を学んだ後、10年ほど同大学で日本語教 師として勤務していた。その後、日本の大学院へ留学して修士号を取得して 
いる。現在はJETプログラムによる国際交流員として、自治体でポルトガル語 翻訳・通訳業務等を行っている。そのため、彼自身日本語とポルトガル語の 言語的差異に敏感であり、ポルトガル語翻訳者及び本調査の協力者として最 適であると判断し、依頼した。なお、ポルトガル語の語義の確認には適宜池 上他編(2014) 及びFerreira（2010）を用いた。

翻訳依頼したすべての項目について一つ一つ見てもらって聞き取りを行 ったため、調査は日数にして2日間、計15時間近くに及んだ。

以下、上記の表3に示した問題点の分類に当てはめて記していく。な お、特に問題があると思われる項目のみを取り上げているため、調査で質問 した全ての項目に触れているわけではない。

\section{6. 意味論的問題}

\section{1. 方言のほうがポルトガル語より意味範疇が広い場合}

まず考えられるのは、東北方言の語のほうがポルトガル語の該当する語 より意味範疇が広い場合である。これは先に具体例として挙げた【あんべわ り】などが該当する。【あんべわり】について東北方言とポルトガル語の語 彙の意味範疇の関係性を図に示すと図4のようになる。

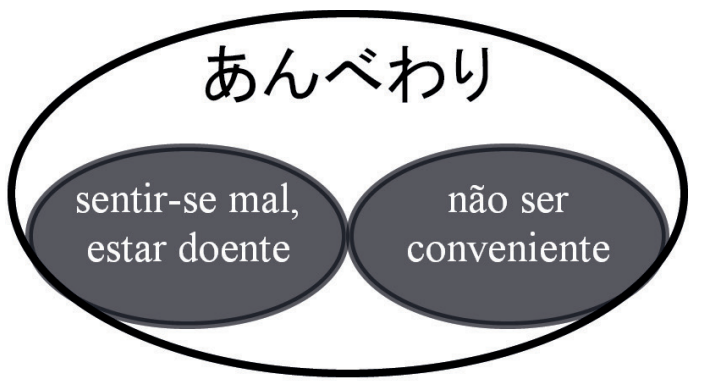

図4.【あんべわり】における東北方言とポルトガル語の意味範疇の関係図

このように、方言の意味範疇がポルトガル語のそれを内包する形になる。

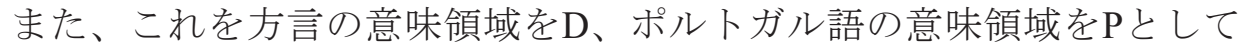
一般化すると、表3のI-a. を図5のように示すことができる。図ではDがEを2つ 内包している図になっているが、これはもちろん必ず2つとは限らず、それ以 上を含む場合もある。この図で示しているのは、東北方言では一つの語で表 すことができる意味を、ポルトガル語では複数の語によってその意味範疇が 分けられているという場合である。 


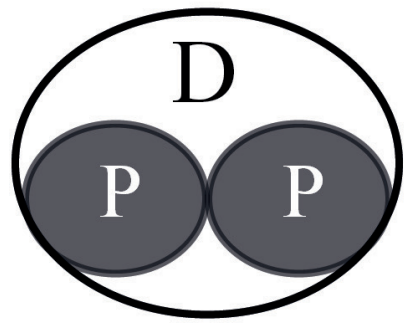

図5. 方言のほうがポルトガル語より意味範疇が広い場合（I-a.型）

以下、このI-a. 型に該当する項目を列挙する。最初に方言項目、次に 方言の意味、その次に対応するポルトガル語の表現や調査で得られたコメン 卜、筆者の補足などを記す。意味に特定の地域のみに見られるものがある場 合は、その意味の前に括弧書きで前述した方言区分の名称を付す。なお、コ メントには意味範疇以外のことについても記している。また、意味的に類似 する方言項目や関連する方言項目に関しては、項目ごとに分けずにまとめて 記している場合がある。

【〜さる】〔つい・うっかり〜する、自然に・勝手に〜する、たまたま〜す る…Sem querer（意図的ではなく、不覚にも）、naturalmente（自然に） 、sozinho（勝手に）、por acaso（たまたま）。【〜さる】は「この ペン かかさん叔」（このペン（で書こうとしてみたらインクが切れてて） 書けない。）や「やっ みらさったや。」（あいつを偶然見かけたよ）の ように、これら全てを指せる。

【あじゃらだ（あじゃらになる）】〔みっともない、いい加減だ〕‥〔みっ ともない〕の訳語としてdesagradávelを用いたが、〔不快な〕という意味 合いを持つ（例：“Aquela pessoa é muito desagradável”（あの人はとっても 不快だ））。いい加減の訳語としてdesapropriadoとしたが、適当という意 味ではde qualquer jeito（あらゆる方法で）のような表現を用いる。人物に 対して言う場合はirresponsável（無責任な）を用いる。

【いいあんべ(いあんべ)】〔ちょうどいい、心地いい〕‥Agradávelは心理 的な良さ、confortávelは快適の意味（ソファーや家など）。身体的には gostosoのほうがよく使うので例文ではgostosoを使用した。ただしgostoso には〔おいしい〕の意味もある。

【いたましい（いだます）】〔もったいない〕Desperdícioは〔もったいな い]だが、日本語で用いられる「あーもったいない。あと5分早く来れば 
あの人に会えたのに。」のような機会の喪失には用いない。あくまでも物 質（いっぱい残す）、金銭（必要以上に使う）、時間（つまらないことに 使う）、能力（持っている能力を発揮しない）、人材などに用いる。夭逝 などの場合にも用いる。【いだましい】は物（*ごはんが【いたましい】 ）ではなく行為（ごはんを残すなんて【いたましい】）について言う。ま た「時間の浪費」については言えない。

【うだで】〔気持ちが悪い、（津軽）大変だ〕№jentoは吐き気をもよおす ほどの不快感を示し、人に対して用いると相手に対しひどい言い方。本当 に吐き気がする場合はenjoadoを用いる。【うだで】については地域差が あるもののcomplicado（大変だ）の意味もある。

【うっつあし（うっちゃし）】〔うるさい〕‥Barulhentoは音量が大きい場合 のみ、煩わしい場合はchato。口論の相手に向かって「うるさい」と放つ 場合はcalarを用いて“Cala a boca!”（口を閉じろ（=黙れ）!）と表現す る。【うっつあし(うっちやし)】は音量にも煩わしい場合にも使える。

【おしょし（おしょうし、おしょす）】【しょし】〔はずかしい】．. Vergonhoso（はずかしい・形容詞）、ter vergonha（恥をかく・動詞）。恥 をかく場合も照れくさい場合も用いる。シャイな人を言う場合はtímido（ シャイ）と表現する。【おしょし（おしょうし、おしょす）】【しょし】 はそのような区別はせず、シャイな性格故に恥ずかしい場合も使える。

【おちる(おじる、おずる）】〔降りる、下車する〕…バス・電車・タクシ 一・階段などはdescer、飛行機・船はdesembarcar。高速道路は高架では なく、高速道路から降りるときはsair（出る）という。（ズボンやパン ツを）下ろす場合はbaixar（もよく使われる）、descer。（例：“descer a calça” (ズボンを下ろす) )

【かせる（かへる）】〔食べさせる〕 ...相手が自分で食べる場合も話者が相 手の口まで運ぶ場合もdar comida a alguém（人に食事を与える）だが、強 制的に「食べさせる」場合はfazer (人) comerになる。【かせる】はどちら にも使える。

【かちやくちや祀】〔物事が進まずイライラ寸る、ややこしい、散らかって いる] …Ficar irritado porque as coisas não andam（物事が進まずにイライ ラ寸る) 、ficar impaciente (イライラする) 、 complicado（ややこしい) 、confuso（煩わしい）、 estar em desordem（散らかっている）。

【かちやぺね】【しっかりしていない、壊れやすい、軽率な〕Não ser 
firme（しっかりしていない）は物だけで、人には使えない。Fracoは人にも 物にも使える。【かちゃぺね】はいずれの意味でも人にも物にも使える。

【かばねやむ】〔なまける（仕事などやらないといけないことをしない）

、サボる〕…〔なまける〕の訳はter preguiça（面倒くささを持つ）とし た。Matar aula ou trabalho（授業や仕事を殺す）は〔サボる〕の意味と なる。

【かまりっこ】〔香り、におい〕 ...Cheiroはbom cheiroかmau cheiroで使い、い い臭いにも悪臭にも使える。Aromaはいい臭いのみで、花などの香り以外 にも使えるが、aroma boaは言わない。

【かんつける（かんずける、かずける）】〔すねる、いじける、ふてくされ る（いやな気持ちがあって相手のいうことを聞かない）、（会津）人のせ いにする〕 ‥Ficar de mau humor（機嫌が悪くなる）、ficar emburrado（ふ てくされる）、culpar alguém（誰かのせいにする）。

【け（けー）】〔食べなさい、ちょうだい、かゆい、（秋田）来なさい〕… 東北方言における多義語。ポルトガル語ではそれぞれcoma（食べなさ い）、dê-me（ちょうだい）、 coçar（かゆい）、venha（来なさい）。

【さすけね】【大丈夫だ〕 …Sem problemaは謝罪への返答に用いる。問題が ないか聞いた時の返答にも“Tem problema se comer isso?”(それを食べて てもいい?）“Sem problema.”（大丈夫だよ。）となる。都合を聞かれ た場合は“Pode ser na semana que vem?”（来週はどう?）“Pode.”（可能 だよ＝大丈夫だよ）になり、勧めを断る時は“não quero”（いやだ）や“ta bom”（結構です）を使う。【さすけね】はそのいずれにも使用できる。 【たがぐ（たんがく、たなぐ）】〔持つ、持ちあげる〕…Segurarは持ってい る状態。持ち上げる場合はlevantar、運ぶ場合はcarregar。【たがぐ（たん がく、たなぐ）】は持つ（運ぶ）行為もその状態もアスペクトで示す。（ 例：「そいつ たがけ。」（それを持って。）、「なに たがってんだ? 」（何を持っているの?））

【ちょす】〔いじる、さわる〕...Tocar（触れる）、tocar com o dedo（指で触れ る）、 tocar com a mão（手で触れる）。摩擦を伴う場合はesfregar（こする、 触る）になる、対象を動かしたりするとmexer（摇さぶる、触る）になる。 【のぜる】〔のどにつまる、吐きそうになる（オエッとなる）〕…Engasgar のどにつまる）、ter vontade de vomitar（吐く気を持つ二吐きそうにな る）。病気でも、喉に歯ブラシを当てても、悪臭を嗅いでもter vontade de 
vomitarは使える。【のぜる】はengasgarとter vontade de vomitarのいずれの 意味にも用いることができる。

【ひとめわりー】【めぐせ（みぐせ）】〔みっともない（人が見たくないと 思う様子、かっこわるい）、はずかしい] ‥Vergonhoso（みっともない） 、feio（醜い、かっこ悪い）。

【ほろぐ（ほろく、ほるぐ）】〔払い落とす、（仙台・会津・中通り）

（財布などを）落としてなくす〕…払い落す〕の意味として訳を espanar（ほこりをとる）にしたが、通常雪には使えない。しかし【ほろ ぐ（ほろう、ほるぐ）】は雪にも使える。主に南東北で用いられる〔（ 財布などを）落としてなくす〕意味としては訳をderrubar（落とす、（ 落として）なくす）にしたが、〔倒す〕の意味もある。また、確実に落 としてなくしたかわからない場合はperder（なくす）を用いる。

【まね】〔だめだ、いけない、（〜しないと）いけない〕‥良くない時 は“Como foi a prova de hoje?”（今日の試験どうだった?）“Foi péssima.” （ダメだった）。都合が悪い場合は“Pode se semana que vem?”（来週は どう?）“Não pode.”（可能ではない＝だめだよ）。当為表現「〜しな いといけない」はter que fazer (ter de fazer)やpreciso fazer（〜必要があ る）で示す。【まね】は良くない時は「あ一、まねや。」（あー、だ めだ。）のように用い、当為表現としては「びょういんさいがねばま ねんだね。」（病院に行かないといけないんだよ。）のように「動詞＋ 否定辞ね+ば」の後に接続する。

【やんだおら（やんたおら、おらやんだ）】〔嫌だ（会津では女性が使うこ とが多い）」‥恥ずかしくて「いやだ」という場合は“Tenho vergonha.”( 恥ずかしい）という。【やんだおら（やんたおら、おらやんだ）】は拒否 する場合にも恥ずかしい気持ちを言う場合にも使う。

\section{2. 方言のほうがポルトガル語より意味範疇が狭い場合}

東北方言の語のほうがポルトガル語のそれより意味範疇が広い場合が あれば、もちろんその逆、つまり東北方言の語のほうがポルトガル語の該 当する語より意味範疇が狭い場合も存在する。

具体例として、【おばんです】を挙げる。【おばんです】は東北地方 全域で用いられる表現で、標準語の《こんばんは》に当たる。これに相当 するポルトガル語はboa noiteであるが、この語は「こんばんは」の意味で 用いられるとともに「おやすみなさい」の意味でも用いられる。つまり夜 
であれば出会った時にも別れの時にも用いることが可能なのである。Boa noite自体は直訳すれば「良い夜」の意味で、実は別れの挨拶としては正し くは“tenha uma boa noite”で「良い夜をお過ごしください」のような意味に なる。おそらく tenha umaが省略されてboa noite自体が「おやすみなさい」 を意味するようになったと思われる。同様に朝会った際のbom dia（おはよ う）、午後会った際のboa tarde（こんにちは）にも、別れの挨拶として朝の 場合は“tenha um bom dia”、昼過ぎでは“tenha uma boa tarde”という表現が存 在している。実際に筆者の経験談として、日本語を挨拶だけ覚えたブラジ ル人と昼に別れた際に「こんにちは」と発言されたことがあるが、これは おそらく“tenha uma boa tarde”を日本語に直す際に“boa tarde”（こんにちは） をそのまま対応させたものだと考えられる。これを図に示すと図6になる。

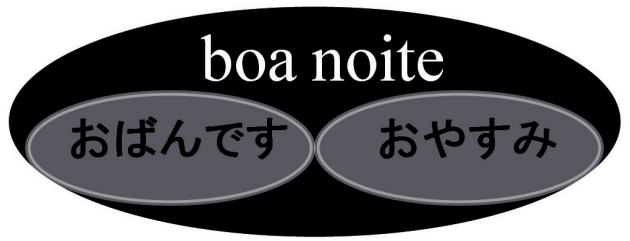

図6.【おばんです】における東北方言とポルトガル語の意味範疇の関係図

一般化すると表 3 の-b. は図7のようになる。I-a.の場合とは正反対 で、PがDを2つ内包している形になっている。もちろん3つ以上を含む場合 もある。この図では、ポルトガル語では一つの語で表すことができる意味 を、東北方言では複数の語によってその意味範疇が分けられているという 場合を示している。

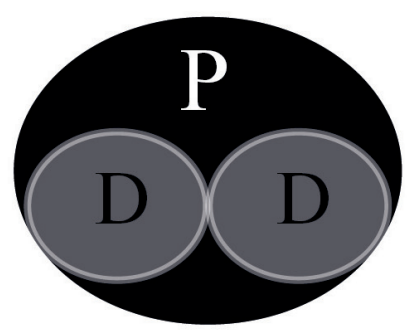

図7. 方言のほうがポルトガル語より意味範疇が狭い場合（I-b.型）

以下、このI-b. 型に該当する項目を挙げる。

【〜える（〜いる）】〔（環境や状況のために）〜できる（「能力があって できる」とは別）]…主に東北地方の日本海側で用いられる【〜える（ いる）】は状況可能だけを示す。例えば海に行って、寒くて泳げる状況で 
はない場合は「およがえね」と言うが、水泳をしたことがないために泳げ ない（泳ぐ能力・技術がない）場合は「およげね」と言う。標準語には状 況可能と能力可能の区別がないが、ポルトガル語もまた可能はpoderのみ で状況可能と能力可能を分けない。

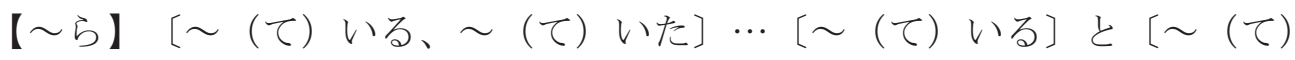

いた」は「estar動詞十現在分詞」なのは同じだが、estar動詞はそれぞれ現 在と半過去でテンスが異なる。【〜ら】はどちらにも使用され、例えば「 あめふって占。」は「雨が降っている。」と「雨が降っていた。」の両 方の可能性があり、文脈で判断される。

【あさぐ】〔歩く〕…歩く〕にはcaminharとandarがあるが、どちらも〔行 く〕〔進む〕などの意味があり、歩かない移動「バスで行く」「船で行 く」などにも使える。【あさぐ】は人間などが足で移動する（=歩く）場 合に用いられる。

【あずましー】〔心地よい、気持ちいい〕‥Agradávelは〔気持ちいい〕〔 心地よい〕の意味だが、人にも使えて〔感じの良い〕という意味にな る。Prazerosoは「喜びを与えられる」という原義から〔気持ちいい〕意味 となるが、マッサージなどの身体的・肉体的な気持ちよさを示す（環境に ついていうことも可能）。そのような意味合いではgostosoも使用できる が、gostosoの場合は〔おいしい〕の意味でも用いられるため、翻訳者は その意味での誤解を避けるために方言集の解説には掲載しなかった。

【あめる】〔料理が腐る、（南部）（髪などが）べたべたする〕 ‥Apodrecer は食べ物と他の物に使える、ただしかなり時間が経っているイメー ジ。Estragarは食べ物（素材か料理かは区別せず、肉・野菜・米・パン・ バター・チーズなど様々なものに使える）。水は腐るという表現は使 えないが、言うならficar ruim（悪くなる）を用いる。牛乳が腐る場合は azedar（酸っぱくなる）を用い、この語はそのようになる食べ物にも使え る。【あめる】は調理したものが悪くなった時のみに使用する。

【うるかす（うるがす）】〔（米などの乾燥した物を）水につける、

(仙 台・会津・中通り）使用後の食器に水を張る、（秋田）話を保留にす る]…（米などの乾燥した物を）水につける]の訳としてmolhar（需ら す）を用いたが、【うるかす（うるがす）】行為は水分のない（少ない） ものに対してのみ行われるため、“molhar (coisas secas como arroz)” ( (米 のような乾燥したものを）濡らす）と補足を加えた。また南東北で用いら 
れる〔使用後の食器に水を張る〕という意味の訳は“colocar água em louças depois de usadas”（使用後に皿に水を入れる）とした。秋田で用いられる 〔話を保留にする〕の意味は“deixar a conversa em pausa”(会話を中断す る）と訳した。なお、翻訳者は上記のようにしたが、〔浸しておく〕意味 ではpôr de molhoといら表現も存在し、こちらは〔使用後の食器に水を張 る〕場合にも使用できる。しかし、molharもpôr de molhoもその対象につ いては制限がないものの、【うるかす（うるがす）】は乾燥物あるいは使 用後の（污れがこびり付いた）食器類に水分を与えてふやかす意味に用い られるため、その対象は限定される。

【おがる】〔大きくなる〕...Crescerは〔成長する〕の意味。子供や植物など が大きくなる場合にも使うが、“o cabelo cresceu”（髪の毛が伸びた）や“a população cresceu”（人口が増加した）のようにも使える。【おがる】は子 供や植物などが大きく成長する時のみに用いる。

【おだつ】〔はしやぐ、調子に乗る〕 ‥犬゚ルトガル語訳としてはalegrarse (喜ぶ) 、 ficar eufórico（わくわくする）など特に悪い意味ではない が、muito eufórico（とてもわくわくする）にすると落ち着いてない感じに なる。「調子に乗る」でも偉そうにしている意味ではarrogante（傲慢な） を用いる、図に乗るような意味ではgabar（誇る）を用いる。【おだつ】 は〔はしゃぐ〕〔調子に乗る〕のみで、ポルトガル語のように程度の違い でプラスの意味にすることはできない。

【がっこ】〔つけもの〕…【がっこ】の訳としてはconserva de legumesとした が直訳すれば「野菜の保存物」で、conserva自体は缶詰や瓶詰を指し、保 存物を意味するのでde legumes（野菜の）を付加してその意味を限定する 必要がある。

【かんじる】【しばれる（すばれる）】〔とても寒い】、【ひやっこい（ひ やっけ、ひやけあ、しやっこい、しやっけ、しやけあ）】〔冷たい]‥ホ ルトガル語frioは〔寒い]と〔冷たい]の意味、さらに形容詞・名詞があ る。また「とても冷たい」場合はgeladoという語がある。なお「暑い・熱 い」場合はquente（形容詞）やcalor（名詞）を使う、ただし calorの場合は 物に使うと「熱」という物理学的な用語になる。方言は気温が低いことを 指す語として標準語形と同一の【さむい（さみ）】〔寒い】に加え【かん じる】【しばれる（すばれる）】といった〔とても寒い】、そして物の温 度の低さを指す語として【ひやっこい（ひやっけ、ひやけあ、しやっこ 
い、しやっけ、しやけあ）】〔冷たい】があり、分かれる。

【きかねー（きかねあ、ちかねー）】〔気が強い（相手の言うことを聞かな い、自分の意見を押し通す、負けず嫌い）」Ner espírito forteとしたが、

〔強い精神を持っている〕という意味なのでいい意味でも使える。【きか ねー（きかねあ、ちかねー）】は〔気が強い〕〔人の言うことを聞かな い〕〔強情〕といった意味のため、いい意味では使わない。そのため方言 集の解説でも “não escutar o que os outros dizem, impor sua opinião, odiar perder” (他の人の言うことを聞かない、自分の意見を押しつける、負けることを ひどく嫌う）と追記した。

【ごんぼほる】〔だだをこねる（わがままを言って言うことをきかない）

」 ...訳としてはfazer birra（強情）、capricho（身勝手）としたが、後者は 〔きまぐれ〕も意味する。【ごんぼほる】は〔だだをこねる〕なので〔き まぐれ〕のような意味はなく、また〔強情〕や〔身勝手〕としても意味が 広い。

【せつね（せずね、へずね）】〔つらい〕…Difícilやduroが相当し、 difícilの ほうが使われるが、こちらは〔難しい〕という意味を含むため意味範疇が 広い。肉体的なつらさよりも精神的なつらさを言うが、 trabalho duro（つ らい仕事）などともいえる。【せつね（せずね、へずね）】は〔（肉体 的・精神的に）つらい〕で、〔難しい〕意味はない。

【たんげ】〔すごく、とても〕…意味としてはmuitoやbastanteが該当する が、bastanteは主に数量が十分な場合に使う。muitoは副詞「すごく」「と ても」以外に形容詞「たくさんの」の用法がある。【たんげ】は副詞の み。

【だんだん】〔もうすぐ、そろそろ〕 ‥犬ルトガル語としてはlogoやdaqui a poucoが相当するが、どちらも時間的にも距離的にも使える。「あとちよ つと」と返事する時は“falta muito?”（まだ?） “Só mais um pouco.”（あと ちょっと。）のような返答になる。【だんだん】は時間的に「そろそろ」 の場合。

【たんぱら】〔短気（すぐ怒る人）】…訳はimpaciente（我慢できない人）と したが、短気だけではなくせっかちな人も含まれる。【たんぱら】は〔短 気〕のみで〔せっかち〕の意味はない。

【つっかけ】〔サンダル〕…これは意味を〔サンダル〕としたが、実は不十 分であった。標準語《サンダル》及びポルトガル語sandáliaは足全体を覆っ 
ていない履物全般が含まれるため、女性用のおしやれなものまで含まれる が、【つっかけ】は簡単に外（家の周囲）に出るためのものなのでファッ ション性に優れたものは指さず、その範囲はかなり限定される。

【なげる】〔捨てる〕‥Jogar foraは直訳では「外に投げる」だがそれで〔 捨てる〕意味になる。その意味ではjogarは〔投げる〕と〔捨てる〕を含 む【なげる】に近いが、jogarには〔（スポーツやゲームで）遊ぶ〕の意 味もある。

【にやにや寸る】〔お腹や胃に違和感がある、お腹や胃の調子が悪い〕…訳 としては〔調子が悪い】という意味の【あんべわり】と同じsentir-se mal が該当する。【にやにやする】はその部位を胃腸に限定しているがポルト ガル語では部位を限定して指寸語はない。

【ねっぱす】〔のりやテープでつける〕…訳としてはcolocarとしたが、こ れだけでは〔（粘着物に関係なく）付ける〕〔身につける（服・時計・ 眼鏡・アクセサリーなど）〕〔置く〕など幅広い意味範疇。またcolar も〔（のりなどで）くっつける〕意味を持つが、〔（学位などを）授与 する〕などの意味も持つ。またgrudarも〔（接着鼡で）はり付ける〕意 味で用いられるが、自動詞として〔粘着力がある〕〔受け入れられる〕 などの意味もある。【㸚っぱす】は〔のりやテープでつける〕のみの意 味。

【までーに】〔寧に〕…Cuidadosamente（注意して）、delicadamente（デリケ ートに）。例文“Lave-os com mais cuidado.”は「もっと気を付けて洗って」と いう意味。お客などを扱う場合はその動詞形cuidar（気を付ける以外に配慮 する、世話する、面倒を見るなど）も使える。しかし【までーに】は物事 を細やかに行う場合に用いるが、お客を扱う場合には使えない。

【んだから（だから）】〔そうだよ、そうでしょう（同意）（原因・理由 を表すわけではない）］…゚゚ルトガル語における相手への同意の表現と してはisso（そう）、exatamente（その通り）。Issoは本来指示代名詞「 それ」なので、当然同意以外の場面でも使う。【んだから（だから）】 にはある情報を相手に伝え、その後相手から「その通りだった」旨を伝 えられた際に「言った通りでしょう?」という意味合いを込めて使う。

【んめ (んめあ、め)】〔おいしい〕…食べて“Estáｇostoso.”（おいしいで

す）といえるし、食べている相手に“Está gostoso?”（おいしいですか?） と聞ける（英語は“It is delicious.”とはいえるが“Is it delicious?”と質問する 
ことができない）。Tá bomも同様に使える。ただし、gostosoには「気持 ちいい」の意味もある。

\section{3. ポルトガル語に適切な語がなく説明的になる場合}

上記I-a. とI-b.の二つの場合では、意味範疇の違いはあるもののおおよ そ該当する語がある場合を見てきた。しかし、ポルトガル語において該当す る語がなく、説明的にならざるを得ない場合もある。

例として【かめっこ】を挙げる。【かめっこ】は主に福島県会津地方 で用いられる表現で、〔人見知りをすること〕を指す。但し、子供の人見 知りのみを指すという制限がある。ポルトガル語においては「人見知り」 に当たる適当な語がなく、そのような場合はvergonha（恥ずかしい）という 語で済ませるという。そのため方言集では“Ficar com vergonha ou incomodado com pessoas que não conhece” (知らない人に対して恥ずかしくなったり嫌に なったりする）と説明的になっている。 ができる。

このような場合、つまり表3のI-c. を図示すると図8のように示すこと

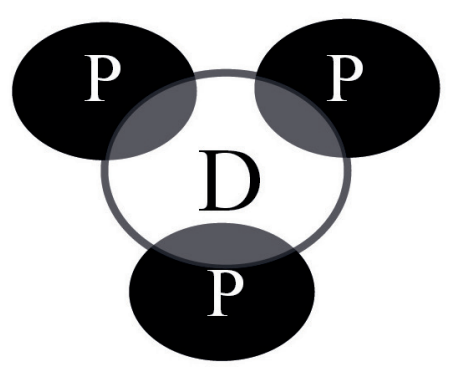

図8. ポルトガル語に適切な語がなく説明的になる場合（I-c.型）

以下、このI-c. 型に該当する項目を列挙する。

【〜がね?（〜がねか?）】〔〜（して）いかない?]‥犬゚ルトガル語では 勧誘の時に「〜しない?」ではなく“Quer〜?”（〜したいですか?）で聞 くので、訳は“Quer (fazer)?”となっており、本来の意味をうまく示すこと が難しかった。また、このようなことからブラジル人日本語学習者は日本 語で「コーヒーを飲んでいきませんか?」と聞きたい時に「コーヒーを飲 みたいですか?」と聞いてしまう。

【〜す（し）】〔〜です、〜ます（丁寧な言い方）〕…東北方言には標準 語の《〜です》《〜ます》に当たる丁寧を示す助詞【〜す（〜し）】が 
あり、その位置については原則としては文末に付く（例：「んだなし」

（そうですね、会津方言）、「がんばっペし」（がんばりましょう、主 に東北地方の太平洋側の方言））が、地域によっては特定の助詞・助動 詞を下接することができる（例：「んだすな」（そうです㸚）、「いぐ 主か?」（行きますか?）、いずれも秋田方言）。ポルトガル語では敬 意を表寸呼称としてo senhor（年上の男性に用いる）やa senhora（年上の 女性に用いる）などはあるが、丁寧語や敬語に当たるような動詞の変化 はない。訳としては「〜です」に対応する語として“"ser，estar”としたのだ がそれは存在動詞の意味としては対応するが丁寧ではない「〜だ」にも 対応してしまう。また「〜ます」はカバーできない。そのため、“forma polida de falar”（丁寧な言い方）と補足することが適当である。

【〜っけ（一）】〔〜（な）んだ（相手に情報を与えるときに使う）〕… 東北方言では相手に情報を与える際に自ら経験したことや見聞きしたこ とに対し「あいっ、あした やすむっていってだっけ。」（あい つ、明日休むって言ってたよ。）や「さっき やまださんの いえの まえ とおったっけが、なんも なぐなってでよ。」（さっき山田さ んの家の前通ったんだけど、何もなくなっていてさ。）というように【 〜っけ（一）】が用いられる。標準語にもポルトガル語にもこれに当た る適切な語がなく、ポルトガル語訳としては語ではなく“usado para dar informações ao interlocutor” (対話者に情報を与えるために用いられる) と説明文になっている。

【えずい（いずい、えんつこい、えんつけあ、えんず）】〔目のごみがご ろごろする、違和感がある、変な感じがする、居心地が悪い～…対応す るそれぞれのポルトガル語として ter um cisco no olho（目にごみがある）

、sentir algo diferente（何か違和感がある）、sentir algo estranhoは（何か 変な感じがする）、sentir-se incomodado（居心地が悪い）という訳にした が、【えずい（いずい、えんつこい、えんつけあ、えんず）】は標準語に も該当する語がなく、衣服などが体にフィットせず気になる場合、体のど こかが不調な場合、何かを相手に伝える際にうまく説明できずもどかしい 場合など、自身に何らかの不都合を感じる際の感覚と言える。方言集の例 文では「その靴かっこいいですね。」という発言に対する返答として「で

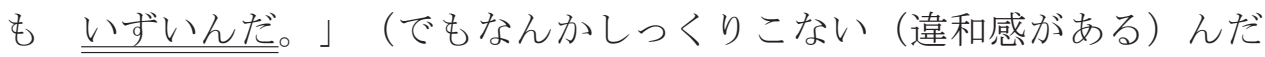
よ。）という文にしたが、そのポルトガル語訳は“Mas tem algo nele que não 
me agrada (que me incomoda).”（でも（その靴に）何か気に入らないところ がある）という表現にしており、やはり項目の訳語では捉えきれずより具 体的な補足を加えたものとなった。

【がな】〔(名詞・代名詞）のもの〕 …各地の方言には標準語《の》のよう な準体助詞が存在する（彦坂2006、福嶋2017）が、福島県（特に会津地 方）を中心とした東北地方の南部では「おれがな／おれのがな」（わた しの（もの））のように用いる準体助詞【がな】が存在する。ポルトガル 語では人称代名詞については所有代名詞meu / minha（私の）、seu / sua（ あなた（あなたたち）の、彼・彼女（彼ら・彼女たち）の（主に書き言 葉））（地域によってはteu / tua（君の）もある）、nosso / nossa（私たち の）という人称ごとあるいは数ごとに異なる語を用いる。あるいは三人称 代名詞については前置詞deと代名詞ele(s)の縮合形dele(s)（彼（彼ら）の、 話し言葉）、同じく前置詞deと代名詞ela(s)の縮合形 dela(s)（彼女（彼女た ち）の、話し言葉）が用いられ、また固有名詞や普通名詞の場合も「de+ 名詞」の形式をとる。このようにポルトガル語においては誰の物かで表現 が異なる。一方【がな】は人称や数、あるいは代名詞・固有名詞・普通名 詞の区別なく誰の場合でも「人物十がな」と下接できる。

【きどころね（きどこね）】〔寝るつもりがないのに（服を着たまま）寝 てしまうこと〕…東北地方の広い範囲では、寝衣に着替えずにうたた寝 をしてしまうことを【きどころね（きどこね）】と表現する。標準語 にも対応する表現が見当たらないが、ポルトガル語にもそれに対応す る適切な語がないので、訳は“Acabar dormindo (de roupa) mesmo sem a intenção de dormir”（寝るつもりがないのに（服のまま）寝てしまうこ と）と、長い説明文になった。

【きやっぱりする（きやっぱりをとる、かわっぺありする、かっぱをとる） 】〔靴の中に水が入る、川に落ちる〕…主に北東北で用いられる【きやっ ぱりする（きやっぱりをとる、かわっぺありする、かっぱをとる）】は、 川に落ちることや、水たまりなどを踏んで靴の中に水が入ってしまうこと を指す。標準語にもポルトガル語にも適切な語がなく、訳としては“entrar água dentro do sapato”（靴の中に水が入る）、“cair no rio”（川に落ちる）と 説明的にならざるを得なかった。

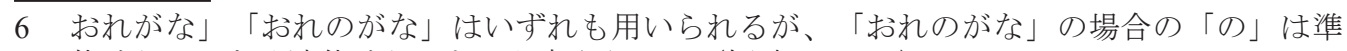
体助詞ではなく連体助詞であると考えられる（福嶋2017: 65）。 
【けっぱる】〔頑張る】…東北方言には標準語《頑張る》に当たる【けっぱ る】といら語があり、例えば津軽方言では相手に「けっぱれ」（頑張れ） と言え、言われた相手は「けっぱら一」（頑張るぞ）と言える。しかし、 ポルトガル語ではこれに対応する語がない。ポルトガル語では相手にかけ る言葉として「頑張れ」に近い意味では、幸運を祈る際には“Boa sorte!”( 幸運を）、元気のない相手を励ます際には“ÂAnimo!”（元気を出して）、奮 起させる際には““Vamos!”（さあ行こう）など、その場面によって用いる表 現が異なる。また、これらの表現を言われたら“Obrigado / obrigada.”（あ りがとう）で返す。なお、方言集のポルトガル語訳としてはそれらを総合 した意味合いで“dar o seu melhor”（その人の最善を外に出す）と説明した が、普段使う表現というわけではない。

【しなっこい（しなっけ、寸なこえ）】〔しなやか、食べ物がなかなか噛み 切りにくい感じ〕…東北方言には弾力性がある様子、特に弾力性のために 噛み切りにくい食品などの様子を指寸語として【しなっこい（しなっけ、 すなこえ）】がある。これに対応するポルトガル語として〔しなやか〕 という意味を訳せばser elástico（弾力性がある）になるのだが、この語は 食べ物にはあまり使わない。そのため、“sensação de uma comida difícil de mastigar”（食べ物が噛みにくい感じ）という説明を付け加えた。

【ジャス】〔ジャージ〕…主に宮城県で用いられる【ジャス】は、ジャージ 一生地を用いた上下セットの運動着のことで、学生などがよく用いる。 標準語の《ジャージ》に当たる。ポルトガル語にはjérseiという語がある が、これはジャージー生地を指すものであり、日本のような上下揃った運 動着の形態は指さない。そこで訳としては“'roupa de jérsei”（ジャージー生 地の服）とより具体的に示したが、それでもジャージ一生地でできた服全 般を指してしまうので、【ジャス】の示寸それを的確には示せなかった。

【ながまる】〔横になる、足を伸ばして休む〕、【数まる】〔（床や地面 に）座る、休む】 …主に北東北で用いられる【ながまる】は、〔横にな る〕や〔足を伸ばして休む〕という意味を持つ。同じく主に北東北で用 いられる【攼まる】も類似する表現ではあるが、こちらは〔（床や地面 に）座る〕と〔休む〕の意味であり、【ながまる】と【ねまる】ではそ の体勢が異なる。【ながまる】の〔横になる〕の訳としてはdeitar-se ( 横になる、「横にする」の再帰動詞）で表現できたが、〔足を伸ばして 休む〕に関しては適切な語がなく、“esticar as pernas e descansar”（足を 
伸ばして休む）と説明的になった。【ねまる】については〔休む〕の意 味は“descansar”で示すことができたが、〔（床や地面に）座る]につい てはsentar（座る）だけでは座る場所が限定されないため、“sentar（no chão)”（地面・床に座る）と補足した。なお、ブラジルでは通常は椅子 に座る。

【はなだんぼ】〔鼻にティッシュをつめること〕…主に福島県では、鼻血や 鼻水が出た際にティッシュをねじって「こより」を作り、鼻の穴に詰める 行為を【はなだんぼ】と言う。ブラジルでは鼻にティッシュを詰める行為 をあまりしないので、該当する語がない。そのため、訳としては“colocar tampão de lenço de papel para nariz sangrando”（出血した鼻にティッシュの 栓を入れる）が適当となる。方言集の例文では「鼻血が出ちやったよ。」 の返答として「あー 恼だんぼ しとげ」（あー鼻にティッシュをつめ ておきな。）という会話を用いたが、ポルトガル語訳は“Ah, limpe o nariz com o lenço.”（あー、ティッシュで鼻をきれいにして）となった。ブラジ ルでこの行為をあまりしないということに関しては、実際に検索エンジン で“nariz lenço”や“nariz lenço de papel”（鼻 ティッシュ）とポルトガル語 で画像検索すると、鼻にティッシュを詰めている画像は1、2件あったもの のそれ以外はほとんどティッシュで鼻をかむ画像だった。一方、同じよう に「鼻 ティッシュ」と日本語で画像検索をすると、出てきた画像のほぼ 全てが鼻にティッシュを詰めている画像であった。

【まぜる】【かでる】〔仲間に入れる〕…主に南東北で用いられる【まぜ る】及び主に北東北で用いられる【かでる】はいずれも〔仲間に入れる〕 意味で、子供が遊びのグループに他の子供を入れる場合や、集団でどこか 飲みに行ったり旅行に行ったりする際に他の人も加える場合などに用いら れる。特に、そのグループに加わりたい人物が「おいどごも孞でれ。」 （わたしも仲間に入れて。）（秋田方言）のように依頼する際によく使用 される。ポルトガル語訳としては該当する語がなく“incluir alguém no seu grupo”（自分のグループに人を入れる）としたが、この表現は普段の会話 ではあまり用いられない。方言集における【まぜる】を用いた例文では「 これから飲みに行こう。」と話している集団に対し第三者が「あ一 おら も まぜてくろ一。（あ一俺も仲間に入れてよ一。）と依頼する場面 なのだが、そのポルトガル語訳としては先の“incluir alguém no seu grupo” を用いず、許可を示す使役動詞deixarを用いた“Ah， deixe-me ir com vocês 
também.”（あー、私もあなたたちと一緒に行かせて。）にした。

【やばつい(やばち）】〔湿って気持ちが悪い、（秋田）手などが污れる、

（伊達）よろしくない、まずい] …福島県を除いた広い範囲で用いられ る【やばつい(やばち)】は、地域による意味の違いはいくつかある ものの、その代表的な意味として〔湿って気持ちが悪い〕というものが ある。具体的には、雨に濡れた時、上から冷たい水滴が垂れてきた時、 生乾きのシャツを着た時など、熱くはない水分による不快感を表明す る場合に用いられ、湿っていても「蒸し暑い」場合にはあまり用いられ ない。ポルトガル語においては「湿気で気持ち悪い」と限定的な語はな く、湿気で気持ち悪かったとしても言うのはestar incomodado（気持ち悪 い）のみ。また、秋田方言で用いられる〔手などが污れる〕という意味 は、sujar（污れる）とした。伊達方言で用いられる〔よろしくない、ま ずい]についてはnão ser bom（よくない）、ser ruim（悪い）とした。

\section{7. 意味論以外の問題}

東北方言からポルトガル語への翻訳上の問題点を取り上げる上で、意味 論のみが問題となるわけではない。本稿においても、いくつかの意味論以外 の問題が明らかになったので、以下に記す。

\section{1. 発音規則}

これに関しては、ポルトガル語が関わる直接的な問題とは言えないが、 方言学習上で理解を助けるものである。主に福島県で用いられる【〜っち や】は標準語《〜れた》に対応する形式である。これは、完了の語形が《つ かれた》《はなれた》《たれた》等のように標準語で「〜れた」に当たるも のは全て規則的に【つかっちや】【はなっちや】【たっちや】のように【〜 っちや】になる。また、完了のみならず受身の《もっていかれた》《やられ た》《なぐられた》もそれぞれ【もってがっちや】【やらっちゃ】【なぐら っちゃ】、可能の《おきられた》《うけられた》も【おぎらっちや】【うげ らっちや】のように規則的に【〜っちや】になる。したがって、少しでも標 準語を学習している者であれば、この規則を知ることによって当該地域で【 〜っちや】を聞いた際に変換することが可能になる。同様に、主に南東北で 用いられる【あるって】は、標準語《歩いて》に対応する形式で、標準語で はイ音便になるところが東北方言では促音便になっている。

\section{2. 語順}

主に北東北で用いられる【〜はんで（～はで）】や【〜すけ（〜す） 】は原因・理由を示す標準語《〜から》に相当する接続助詞である。ポル 
トガル語ではportantoが該当する。これはやや書き言葉的ではあるが、使用 する場合は前件に原因・理由を置き、後件の直前にのみ用いる。なお、 por isso（直訳としては「そのため」になる）もportantoと同じように用いるこ とができる。また、ブラジル人としてはporqueもよく用いるという。これは portantoと異なり後件に原因・理由を置いてその直前にporqueを用いる。さ らに口語ではcomoなども用いられるが、comoの場合は文頭に置き、前件が 原因・理由になる。

東北方言（ここでは津軽方言）【〜はんで】及びポルトガル語 portanto、porque、comoにおいて、「砂糖がなくなってきたから、砂糖を買っ てきて。」という文を例にすると、それぞれ以下のようになる。

津軽方言

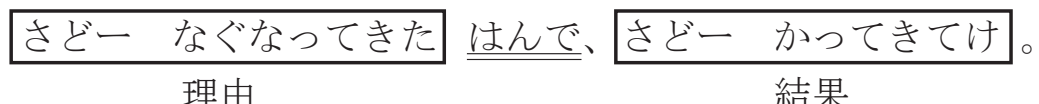

ポルトガル語

O açúcar já está perto de acabar, portanto compre açúcar.

理由 結果

Compre açúcar, porque o açúcar já está perto de acabar.

結果 理由

Como o açúcar já está perto de acabar, compre açúcar.

理由 結果

このように、【〜はんで（～はで）】（【〜すけ】も）は理由を示す 節（前件）に後接し、結果（例文では依頼）を示す節の直前に置かれている のに対し、ポルトガル語に関しては、portantoは同じく結果を示す節の直前 に置かれるものの結果を示す節（後件）に前接、porqueは原因を示す節に前 接、comoは文頭かつ理由を示す節に前接とそれぞれ異なる（表6）。 
表6.【はんで】【すけ】及びportant、porque、comoの位置関係

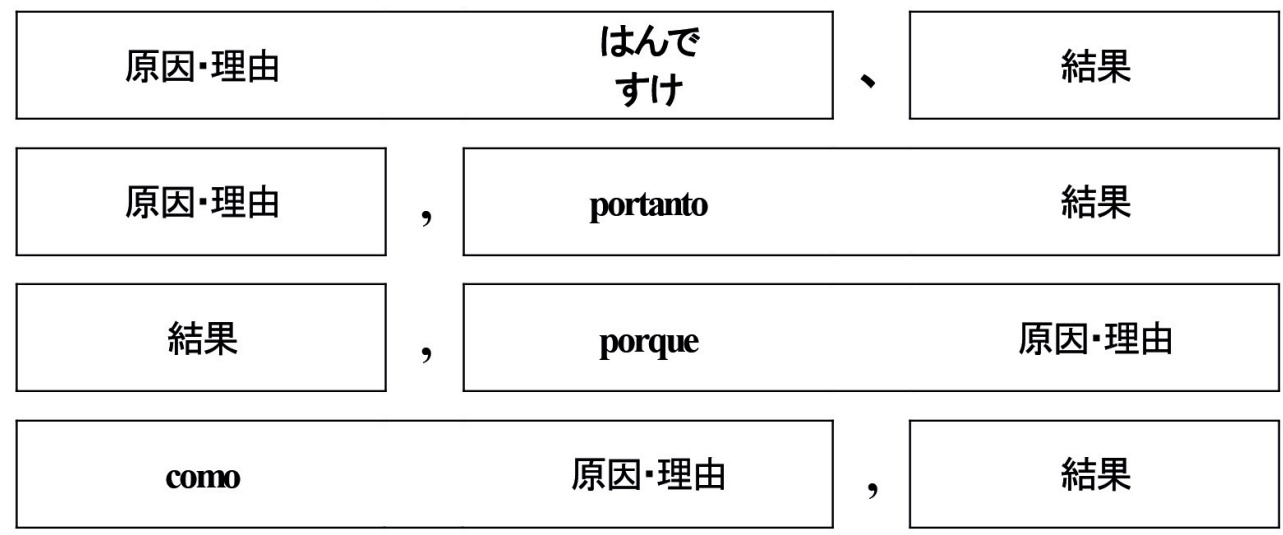

つまり【すけ】【はんで】はportant、como、porqueと同様の意味を持つ ものではあるが、位置関係も同様だと思ってしまうと、因果関係が逆になる などの可能性がある。

\section{3. テンス・アスペクト}

主に青森県津軽地方で用いられる動詞【おたった】は、標準語でいう と《疲れた》になる。【おたった】は現在形としては【おたる】になるのだ が、【おたる】という形式よりもむしろ【おたった】のほうがよく使われ る。ポルトガル語ではcansar-seという動詞、あるいはexaustoという形容詞を用 いるが、テンス・アスペクトの制限は特にない。

また、主に北東北で用いられる【どでんした（どでした）】は、標 準語の《びっくりした》に当たるが、現在形【どでんする（どでする）】 よりも【どでんした（じでした）】で用いられることが自然である。ポル トガル語の該当する表現はassustar-se（「驚かす」の再帰動詞）やlevar um susto（驚きを受ける）であるが、これらはテンス・アスペクトに制限なく 使える。

このように、東北方言とポルトガル語においてテンス・アスペクトの制 限に違いがある場合も見られた。

\section{4. 人称}

【うすらかすらする（うらからする）】は主に福島県や岩手県などで 用いられる表現で、標準語では《うろうろする》に近いのだが、完全には 一致せず、〔周りに気を配らないで、うろうろしたりもたもたしたりする （ことによって最終的に周りに迷惑をかける）」というかなり限定的な意 
味合いを持つ。ポルトガル語の訳語としてvagarやvaguear（目的もなく歩 く）が近い意味を示寸が、これらは一人称でも用いられ、人称に限定はな い。しかし、【うすらか寸ら寸る（うらからする）】は前述の通りマイナ スのイメージがあるためか、主語に一人称が置かれることはない。なお、 ブラジル・ポルトガル語の口語としてzanzar（（何もせずに）ふらふら歩 く）というものがあり、こちらはマイナスのイメージを含み一人称があま り使えないが、やはり意味・人称ともに【うすらかすらする（うらからす る）】とは差異が見られる。

同様に、主に東北地方全域で用いられる【ちゃっちゃど（ちゃっち やと、ちゃちゃど）】や、主に宮城県以北の太平洋側で用いられる【わら わらど】はどちらも標準語でいう《さっさと》に当たる語である。用法と しては主に発話の相手が【ちゃっちゃど（ちゃっちゃと、ちゃちゃど）】 【わらわらど】の行為の対象となり、「泀やっちゃど せ一。」（さっ さとしろ。）や「わらわらど やれ。」（さっさとやれ。）のような命令 や、「ちやっちやど するべ。」（さっさとしよう。）といった勧誘、あ るいは「ちやっちやど し初がらおぐれんだ。」（さっさとしないから 遅れるんだ。）といった相手を責める場合などに用いられる。つまり、

【ちやっちゃど（ちゃっちゃと、ちゃちやど）】や【わらわらど】を用 いる時の主語は二人称であるという場合が自然であり、「*私は【ちゃっ ちやど】する。」のような場合は不自然である。ポルトガル語においては imediatamente（すぐに）、rápido（早く）などの語が対応するが前者は長い ので後者がよく用いられ、またLogo（間もなく）も使われるが、これらは 特に人称の制限はない。

また、主に青森県津軽地方で用いられる【〜びょん（〜べお）】は標 準語の《〜だろう》に相当する推量の助詞であるが、こちらは「あすゆ ぎふるびょん。」（明日は雪が降るだろうね。）のように主に三人称に 用いられる。ポルトガル語ではprovavelmenteという副詞もあるが、talvezの ほうが一般的に用いられる。また、 achar que 〜 ( と思う) という表現と ほぼ同義で、言い換え可能であるが、これらは人称に制限がなく、一人称 などにも用いられる。

このように、主語に立つことのできる人称に差異が見られる場合があ った 


\section{5. 対象}

主に福島県会津地方で用いられる【おんずくなし（おんじくなし）】 は、標準語《ばか》に近い意味で用いられる。ポルトガル語ではidiotaが該 当するが、これは「愚かな行為をする人」にも「愚かなこと」にも使える。 しかし、【おんずくなし（おんじくなし）】は人や動物、あるいは機械など にのみ使用され、事には使用しない。なお、口語としてburroも《ばか者》の 意味で用いられるが、こちらは本来《ロバ》を指寸語であり、その意味では idiotaよりも指し示寸意味が広い。

また、主に秋田県で用いられる【ほろだぐ】は、標準語《払い落す》に相 当する語である。ポルトガル語でこれに対応寸る表現はespanarなのだが、これ はほこりを払う時に使えるものの、方言集の例文「まず ゆき ほろだげ。」

（とりあえず雪を払い落としなさい。）のような雪の場合に用いることができ ない。雪を払い落としたい場合はtirar（出す、取る、取り除く）を用いることに なるが、これはあくまでも〔取り除く〕なので、払い落とすという動作には限 定されない。また、砂の場合はlimpar（きれいにする）を用いる。なお、これは I-a.型として取り上げた【ほろぐ（ほろう、ほるぐ）】にも同じことが言える。

このように、動作の対象によって表現が違うということがあった。

\section{6. 言い回し}

東北地方全域で用いられる【やっこい（やっけ、やけあ）】は、標準語で 《柔らかい》に当たる語である。ポルトガル語ではmoleがこれに当たり、体・ マット・果物・肉などにも使える。しかし、〔考え方などに柔軟性がある〕意 味として東北方言では【頭がやっこい】（標準語《頭が柔らかい》に相当）と 言えるのだが、ポルトガル語では「頭が柔らかい」という表現はなく、同様の 意味を指寸表現としてcabeça aberta（開かれた頭）というものを用いる。一方、 主に北東北で〔頑固者〕の意味で用いられる【じょっぱり】に当たるポルトガ ル語の表現はcabeça dura（かたい頭）と「かたい」を使用するので、東北方言と ポルトガル語においてそれぞれの対義語の対応関係が異なる。つまり、ポルト ガル語話者が【やっこい（やっけ、やけあ）】をmoleと理解しても、「あたま やっこくしろ。」（柔軟に考えなさい。）と言われた際には何が言いたいの か理解しがたいという問題が起こる可能性が考えられる。

このように、東北方言とポルトガル語で言い回しに関する違いが見ら れた。 


\section{8. まとめ}

以上、本稿では『東北地方の外国人住民のための「くらしの方言集」』 を用いて、東北方言からポルトガル語への翻訳の際に見られる問題点につい て考察した。

本稿における調査を踏まえて、東北方言からポルトガル語への翻訳上の 問題点を改めて分類すると、「I 意味論的問題」には前述のように「I-a. 方 言のほうがポルトガル語より意味範疇が広い」「I-b. 方言のほうがポルトガ ル語より意味範疇が狭い」「I-c. ポルトガル語に適切な語がなく説明的にな る」の3つの場合が存在し、その他にも「II 意味論以外の問題」として「IIa. 発音規則」「II-b. 語順」「II-c. テンス・アスペクト」「II-d. 人称」 「II-e. 対象」「II-f. 言い回し」の6つの問題点の存在が明らかになった。こ れらを表にまとめると、表7のように示すことができる。

表7. ポルトガル語への翻訳上の問題点

\begin{tabular}{|c|c|}
\hline \multirow{3}{*}{ 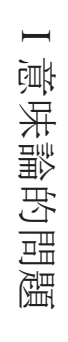 } & I-a. 方言のほうがポルトガル語より意味範疇が広い \\
\hline & I-b. 方言のほうがポルトガル語より意味範疇が狭い \\
\hline & I-c. ポルトガル語に適切な語がなく説明的になる \\
\hline \multirow{6}{*}{ 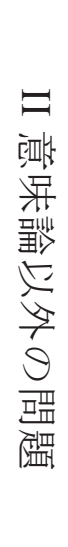 } & II-a. 発音規則 \\
\hline & II-b. 語順 \\
\hline & II-c. テンス・アスペクト \\
\hline & II-d. 人称 \\
\hline & II-e. 対象 \\
\hline & II-f. 言い回し \\
\hline
\end{tabular}


本稿では、地域の外国人住民の方言理解を考える上で、標準語と諸言 語の対照や方言と英語の対照のみでは不十分であること、そして外国人住 民の居住地域の方言と彼らの母語（本稿では東北方言とポルトガル語）の 直接的な対照が有用であることを一定程度示すことができた。本稿におけ る東北方言とポルトガル語の対照研究が、ポルトガル語を母語とする現在 の、そして将来の東北地方の外国人住民の方言学習を考える際の参考にな れば幸いである。

\section{参考文献}

飯豊毅一、日野資純編(1982)『講座方言学4一北海道・東北地方の方言一』 国書刊 行会

池上岑夫、金七紀男、高橋都彦、富野幹雄、武田千香編(2014)『現代ポルトガル語辞 典 $(3$ 訂版 $)$ 和ポ付』白水社

太田亨 (2000)「日本語とポルトガル語の先行性アスペクトをめぐる考察」『日本語と ポルトガル語 (2)： ブラジル人と日本人との接触場面』 国立国語研究所 pp. 93-126.

儀保ルシーラ悦子 (2014) 「ブラジル・ポルトガル語のアスペクト・テンス体系一日本 語のアスペクト・テンス体系との比較研究一」『ロマンス語研究』47 ロマンス 語学会 pp. 1-10.

後藤典子 (2015)「医療・介護現場の方言を外国人はどう理解するか一他地域出身日本 人と比較して一」『日本語教育』161 日本語教育学会 pp. 42-49.

斎藤敬太 (2017)『東北方言の外国人住民のための「くらしの方言集」』 平成28年度 笹川科学研究助成により印刷

斎藤敬太 (2018a)「外国人住民向け方言理解支援ツールに関する研究一『東北地方の 外国人住民のための「くらしの方言集」』の作成とその評価一」津田智史編『「 多文化共生社会に向けての災害時コミュニケーションに関する総合的研究」報告 書』（津田智史代表科研費報告書） 宮城教育大学 pp. 72-85.

斎藤敬太 $(2018 b) 「 『$ 東北地方の外国人住民のための「くらしの方言集」』作成に 向けた語彙・文法項目の使用実態調査」『武蔵野大学教養教育リサーチセンタ 一紀要 The Basis』8 武蔵野大学教養教育リサーチセンター紀要編集委員会 pp. 129-139.

斎藤敬太、志喜屋カロリーナ（2015）「中南米系外国人集住地域の言語景観における 伝達意図の阻害要因」『日本語研究』35 首都大学東京・東京都立大学日本語・ 日本語教育研究会 pp. 113-123.

総務省 (2017) 「政府統計の総合空口GL02020101」https://www. e-stat. go.jp/SG1/ estat/GL08020103. do? 
_toGL08020103_\&1istID $=000001177523 \&$ requestSender $=$ dsearch

竹田晃子 (2012)『東北方言オノマトペ（擬音語・擬態語）用例集一青森県・岩手県 ・ 宮城県・福島県一』 国立国語研究所

日本方言研究会編(1964)『日本の方言区画』 東京堂

彦坂佳宜 (2006)「準体助詞の全国分布とその成立経緯」『日本語の研究』2 （4）日 本語学会 pp. 61-75.

福嶋秩子 (2017)「方言分布の総合と比較から見る方言の地域差と変化」『方言の研 究』4 日本方言研究会 pp. 53-76.

堀永乃 (2009)「「介護のための日本語教室」にみる多文化共生社会づくりへの取り組 み一浜松市国際交流協会の実践から一」『日本語学』28-6 明治書院 pp. 7987.

本堂寛(1967)「岩手県方言の系統と区画について」『一関工業高等専門学校研究紀 要』1 一関工業高等専門学校 pp. 48-76.

山下暁美 (2014)「命綱としての日本語一「災害時命綱カード」の提唱一」『応用言語 学研究』16 明海大学大学院応用言語学研究科紀要編集委員会 pp. 57-74.

Ferreira, Aurélio Buarque de Holanda. Dicionário Aurélio da língua portuguesa. $5^{\mathrm{a}}$ ed. Curitiba: Positivo, 2010.

謝辞

本研究は、公益財団法人日本科学協会の平成28年度笹川科学研究助成に よる助成を受けたものである。また、調査に協力していただいたWadison Melo 氏にお礼申し上げます。 